\title{
A PROPOSAL TO IMPROVE THE COST TO BENEFIT RELATIONSHIPS IN THE MEDICAL PROFES- SIONAL LIABILITY INSURANCE SYSTEM
}

\author{
MYron F. STEVES, JR.*
}

Prior to the last ten years, the cost of medical malpractice insurance was not a major concern of the health care system. As a percentage of gross revenues, the cost of coverage was not significant, ${ }^{1}$ and the premium expense had no marked effect on the way in which practitioners and health care institutions delivered their services. ${ }^{2}$ Providers bought a contract where the primary interest was defense. ${ }^{3}$ The public benefited

* Myron F. Steves, Jr., CPCU, is completing his studies for a Ph.D in Business and Applied Economics with a Specialization in Insurance at the University of Pennsylvania, where he studied under a S.S. Huebner Foundation Fellowship. Mr. Steves worked as a systems analyst/management engineer at the Graduate Hospital of the University of Pennsylvania from 1969 to 1973. He is currently a partner in an excess and surplus lines imsurance agency in Houston, Texas, where he specializes in placing medical hability insurance.

THE FOLLOWING CITATIONS WILL BE USED IN THIS ARTICLE:

U.S. Dep'T OF Health, Education and Welfare, Report of the Secretary's Commission on Medical MaLpractice (1973) [heremafter cited as MEdical MalpracTICE REPORT];

Questionnaire Re Medical Professional Liability Insurance, Technical Appendix, in Hearings on S. 482, S. 215, S. 188 Before the Subcomm. on Health of the Senate Comm. on Labor and Public Welfare, 94th Cong., 1st Sess. 552-601 (1975) [hereinafter cited as Technical Appendix].

1. See Steves, Medical Malpractice In Perspective, 28 CPCU ANnaIs 209, 215-16 (1975); Steves \& McWhorter, Notes on the Malpractice Insurance Market, $28 \mathrm{CPCU}$ Annals 224, 232-33 Table XI (1975). See also Kendall \& Haldi, The Medical Malpractice Insurance Market, in MEDICAL MALPRACTICE REPORT Appendix 494.

2. Although premium expense has not been a factor historically, the fear of malpractice litigation is said to result in an overutilization of many diagnostic studies and a possible underutilization of aggressive but hazardous forms of therapy. See Project, The Medical Malpractice Threat: A Study of Defensive Medicine, 1971 DukE L.J. 939. See also Weinberger, Malpractice-A National View, 32 ARZ. MED. 117 (1975). But cf. Beruzweig, Defensive Medicine, in Medical Malpractice Report Appendix 39-40.

3. The first obligation im medical professional liability policics has always been "to defend"; until recently, few policy contracts allowed insurers to settle a clami without provider approval. See 1 R. LoNG, THE LAW OF LIABIIITY INSURANCE $\$ 12.08$ (1975); 2 D. Louisell \& H. Williams, Medical Malpractice $\Uparrow 20.06$ (1974). The predecessor organization of the Medical Protective Insurance Company of Fort Wayne, Indiana, was a physician's defense league permitted by an act of the Indiana Legislature in 1889. Medical Protective Co., Defending tHe Doctor 3. The New York group insurance plan was named "The Professional Medical Liability Insurance and Defense Program." The Canadian and English plysician organizations, in name and in attitude, are defense leagues. 
to the extent that the assets of particular providers were not impaired by successful litigation and that providers were reminded of their legal responsibilities. Occasionally, a victim of a significant injury, alleged to have been negligently caused, received compensation.

In more recent years the price of professional liability insurance lias increased to the point where it is no longer an insignificant proportion of provider gross revenue. ${ }^{4}$ Furthermore, if the distribution of premium cost among the various types and specialties of providers is considered, the impact of increased premiums is multiplied. The direct cost of insuring the professional liability liazard is approaching the level where it is not unreasonable to assume that the price level and structure of the insurance system affects the quantity and quality of services rendered by health care providers. ${ }^{5}$

Given the escalation of insurance costs, it is in the public interest to evaluate the consumer benefit derived from the provider's malpractice premium. Altering the patterns of liability exposure which insurance inust protect in the liealth care system may increase incentives for quality control and injury prevention as well as provide a inore stable foundation for an insurance market in the face of rising premium costs. Although insurance is a follower with respect to legal trends, it may be innovative with respect to exposure base and rating in ways that place empliasis on compreliensive risk management. This Article suggests sucl an innovation in the form of a shift in liability exposure and premium cost burdens which, while departing radically from the current focus on individual practitioners, will benefit the public through encouragement of improved quality of care while easing the ever-increasing fimancial burden of providers.

\section{The Differing FinanCial INTERESTS OF PROVIDERS AND PATIENTS}

Under the system of civil jurisprudence that exists in the United States, providers may be lield liable for damages arising out of the rendering of, or failure to render, professional services when these services depart from an accepted standard of care and result directly in damage to the patient. ${ }^{6}$ It is the risk of financial loss resulting from this

4. See notes 58-75 infra and accompanying text.

5. But see Brook, Brutoco \& Wrilliams, The Relationship Between Medical Malpractice and Quality of Care, 1975 Duks L.J. 1197, 1209-15.

6. See C. Wasmuth, Law For the Physician 20-21 (1966); Purdue, The Law of Texas Medical Malpractice, 11 Houston L. REv. 2, 21 (1973). See also A. Holder, medical Malpractice Law 1-61 (1975). 
liability that is the immediate concern of providers, a concern which motivates them to purcliase imsurance and encourages them to establisl incident-reporting systems and other risk management techniques to prevent or minimize the impact of liability claims. While professional and ethical considerations, supported by accreditation, licensure and the stimulation of third-party reimbursement programs, ${ }^{7}$ do give providers a substantial stake in reducing injuries and momitoring the quality and quantity of patient service, the liability claim and the insurance premium necessary to protect against the claim are explicit and substantial costs that no provider may ignore.

The fimancial interests of the patient population differ from those of the providers who pay for protection against potential civil liability. Consumers are concerned with injuries per $\mathrm{se}^{8}$ because, both imdividually and collectively, injuries reduce wealth. Patients have a direct economic and social cost irrespective of the existence of transfer mechanisins to shift or spread the burden of harm which lras occurred. Firstor third-party insurance programs may make implicit costs explicit or may reallocate expense, but total costs are not reduced unless the frequency and severity of injuries are reduced. From the patient viewpoint, of course, injuries are primary even if the narrow ground of a provider's civil liability is considered. ${ }^{9}$

The differing financial interests of providers and patients with respect to injuries are highlighted by reference to available infornation on the relative numbers of injuries, negligent acts, and malpractice clains that occur in the liealth care system. In a 1972 study conducted at the request of the Department of Health, Education and Welfare

7. Licensing requirements for medical practitioners are established at the state level, cf. C. WASMUTH, supra note 6, at 31-32, and represent minimum qualifications. Accreditation is done by a variety of organizations, the most important of which is the Joint Commission for the Accreditation of Hospitals (JCAH). Third-party payors, particularly the Medicare and Medicaid programs administered by the Department of Health, Education and Welfare, impose review standards which emphasize the control of utilized services which the programs are requested to reimburse.

8. Injuries, $\mathrm{m}$ this context, are defined as harm caused or aggravated in the course of medical treatmeut. It is harm that occurs because of a provider's active intervention or failure to intervene where such was required by medical convention. The term, as used herein, does not include all deterioration of human functions that occur because of disease, illness, accident, or aging. Nor does it include discomfort not considered harmful which is a byproduct of accepted diagnostic or therapeutic regimens. See Pocincki, Dogger \& Schwartz, The Incidence of Iatrogenic Injuries, in MEDICAL MalPRACTICE REPORT Appendix 50, 51.

9. Adverse and untoward results of medical supervision aud treatment are, of course, the basis for nearly every medical malpractice claim. See Medical MalpracTICE REPORT 24-25. 
Secretary's Commission on Medical Malpractice, ${ }^{10}$ medical records were selected at random from the discharge records of two hospitals. When the 821 records in the sample were analyzed for iatrogemic injuries, ${ }^{11}$ the overall injury rate at the two sample hospitals was found to be approximately 7.5 percent. $^{12}$ If this percentage is apphed to the total number of patients discharged from all health care institutions, it is estimated that over 2.6 million persons are injured annually in the course of medical treatment. ${ }^{13}$

Of the injuries observed in the study, forty-four percent were classified as "minor temporary" and thirty percent as "inajor temporary." Permanent injuries classified as "significant," "1najor," "grave," and "death" accounted for eighteen percent of the total. ${ }^{14}$

It was beheved that twenty-nine percent of the injuries observed in this retrospective sample were due to negligence. Applying the results of the sample to the total number of discharges that occurred in the two hospitals, the survey indicated that 517 injuries may have been negligently caused. ${ }^{15}$ However, the estimated number of malpractice claims to be filed by patients discharged in 1972 against the hospital and its medical staff was only thirty-one. ${ }^{16}$

10. Pocincki, Dogger \& Schwartz, supra note 8.

11. Iatrogenic is derived from the Greek word iatros, or physician. It refers to physician-caused injuries. See note 8 supra.

12. Pocincki, Dogger \& Schwartz, supra note 8 , at 63 . The authors of this study believed that the injury rate observed was the lower bound for the institutions surveyed. Charts classified as not involving injuries at any stage were excluded, while charts classified as involving injuries were included at several stages, with a chance for rejection at each stage. Id. at 54.

13. The estimate is based on the 35,506,190 admissions for all types of health care institutions in the United States in 1974. AM. Hospital Ass'v, Hospital Statistics 13 Table 1 (1975).

14. Pocincki, Dogger \& Schwartz, supra note 8, at 56-57. "Minor temporary" includes improperly set fractures and infections induced by operations or lack of antibiotics. "Major teinporary" includes burns, broken ankles from falls, significant drug side effects, or severed nerves or tendons. "Permanent major" includes paraplegia, blindness, or brain dannage. "Grave" ineans quadriplegia, severe brain dainage, or life-long care. For another classification scheine for severity of injury, see Rudov, Myers \& Mirabella, Medical Malpractice Insurance Claims Files Closed in 1970, in Medical MaLPractice REPORT Appendix 1, 9-11.

The reviewers used a confidence scale of one to six to indicate the strength of their responses froin "unsure" to "confident." In ninety-three percent of the cases the reviewers were above four on this confidence scale, with six being the inode response.

15. Pocincki, Dogger \& Schwartz, supra note 8, at 50. The confidence response averaged 2.3 on the scale explained in note 14 supra. However, records involving injuries were reviewed for the standard of care rendered. No attempt was made in this survey to ascertain the quantity of negligent or substandard care that did not result in imjury.

16. See id. at 62 . 
In another study cited in the H.E.W. report, "accidents attributable to sanctioned and well-intentioned diagnosis and therapy were noted in about five percent of all patients admitted to medical wards."17 Finally, a study of over 1,000 patients extending from August 1, 1960, to March 31,1961 , atteinpted to tabulate noxious responses or "episodes" occurring among patients if they resulted from acceptable diagnostic or therapeutic measures deliberately instituted in the hospital..$^{18}$ Reactions arising froin inadvertent errors by plysicians or nurses were excluded. Nevertheless, twenty percent of all patients suffered some type of accident, and 4.7 percent of the accidents were classified as "inajor."19

\section{The Frequency and SeVerity of Medical Negligence}

Information on the quality of health care services is scarce but there are indications that much of the care rendered does not ineet minimal standards. Two studies, now somewhat dated, attempted to measure the qualitative level of inedical care rendered in this country. In 1956, Osler Peterson, a staff nember of the Rockefeller Foundation, and his team of doctors watched North Carolina plysicians treat pa-

17. Barr, Hazards of Modern Diagnosis and Therapy-The Price We Pay, 159 J.A.M.A. 1452, 1456 (1955).

18. Schimmel, The Hazards of Hospitalization, 60 ANNALS OF INTERNAL MED. 100 (1964).

19. Id. at 108. Information obtained from a hospital association corroborates these findings in a somewhat different way. In the twenty years of that program's existence approximately 700,000 incident reports were filed with the insurer. Incident reports cover an assortment of occurrences, mcluding slips and falls, medication errors, equipment failures, losses of personal belongings, adverse reaction to therapies, hospital-acquired infections, and anesthesia accidents and surgical mishaps. What percentagc of these reports involved injuries is not known, but it would be reasonable to assume that a significant portion involved some mishap that either caused or might have caused physical harm. In this same period 15,000 clains were filed. Of these reported claims, a hospital association source estimates that only fifteen percent were associated with previously filed incidents. Personal interview with Douglas Dutton, California Hospital Association, Spring 1975. The figures are rough estimates based on experience from 1955 through 1973. Recently, the computer claim analysis used by the insurer was modified to indicate when a claim was first reported as an incident.

According to one estimate of the incidence of hepatitis related to transfusions, two million people receive blood in the course of a year. Of those receiving blood, 1.5 percent $(30,000)$ develop overt hepatitis which requires hospitalization. Of these, ten percent $(3,000)$ die from an acute episode. Those surviving are hospitalized for a period averaging twenty-eight days, with an additional month required for convalescence. A conservative estimate of the economic loss from this injury alone is $\$ 175$ million per annum, assuming the incident rates are accurate. See Havighurst \& Tancredi, "Medical Adversity Insurance" $-A$ No-Fault Approach to Medical Malpractice and Quality Assurance, 51 MILBANK MEMORIAL Fund Q. 125, $154 \mathrm{n} .10$ (1973), reprinted in 613 INs. L.J. 69,90 n.10 (1974). 
tients in their offices. Peterson concluded that sixty percent of the therapy was below acceptable standards. ${ }^{20}$ Later, from 1962 to 1964, a medical team from the Columbia Umiversity School of Public Health studied a random sample of patients in the New York City lospitals. In this study forty-three percent of the care was ruled less than "good" and twenty-three percent was labeled "poor."21 "Below acceptable standards" and "poor" do not necessarily reflect care whicl would result in tort hability if the care produced injury, for much depends on the standards chosen as normative and the objectivity and perception of the reviewer. However, the magnitude of these statistics suggests that the negligence may be extensive. ${ }^{22}$

The size of the negligence umiverse may also be related to patterns of surgery performed in the Umited States. The fee-for-service systein, for whatever advantages it may have, has the unfortunate disadvantage of placing economic incentives on the side of performing more operations. ${ }^{23}$ Furthermore, this system encourages more radical operations and procedures which in another environment might more readily be referred to surgeons with special interests in a particular disease. Although this type of "negligence" is difficult to prove in individual cases, there are indications that a significant amount of such surgery is beimg performed. ${ }^{24}$

20. Peterson, Andrews \& Spain, An Analytical Study of North Carolina General Practice 1953-54 (pt. II), 31 J. MEd. Educ. 1 (No. 12, 1956). See Cordtz, Change Begins in the Doctor's Office, Fortune 84, 132 (Jan. 1970).

21. Cordtz, supra note 20 , at 132.

22. Other more recent studies lend credence to the results of these earlier attempts to assess the quality of medical care. See Roddis \& Stewart, The Insurance of Medical Losses, 1975 DURe L.J. 1281, 1298-99 \& n.68; Brook, Brutoco \& Williams, supra note 5, at 1201-02. See also Rensberger, Unfit Doctors Create Worry in Profession, N.Y. Times, Jan. 26, 1976, at 1, col. 1 .

23. A study by a House of Representatives subcommittee found that approximately 2.4 million unnecessary surgeries were performed in 1974, at a cost to the American public of $\$ 4$ billion. Approximately 11,900 deaths were attributed to such unnecessary procedures. SUbCOMm. ON Oversight \& Investigations, House COMm. ON INTERstate \& Foreign Commerce, Cost \& Quality of Health Care: UnNecessary SurGERY 5-6 (Subcoinm. Print, Jan. 1976).

24. Crile, The Surgeon's Dilemma, HARPERs 30-38 (May 1975). Excess surgery is significant because of the inherent risks of operations and anesthesia. Dr. Crile indicates that mortality rates from appendicitis, including deaths resulting from the surgery itself, are highest in the areas where more appendectomies occur. Under the fee-forservice system, patients undergo surgery at more than twice the rate of subscribers to prepayment health plans (sixty-nine versus thirty-three per 1,000). Id. at 30 . The lower rate is comparable to surgery rates in Western European countries. A comparison between fee-for-service and prepayment plans in the District of Columbia revealed that the former group had eighty-six percent more appendectomies, 250 percent more tonsillectomies, and fifty-two percent more hysterectomies than a similar group covered by 
The use of such surgical practices raises the question whether economic incentives in the health care system are misplaced. Moreover, the issue of negligence is raised to the extent that injuries are increased when unnecessary surgery is performed or the best resources available are not used. ${ }^{25}$ Even though imprudence of this type may not produce a verdict for the plaintiff except in the most flagrant case, such activity should not be excluded froin the broad defmition of negligence. ${ }^{26}$

Despite a lack of comprehensiveness in the studies and surveys cited, available information does support the proposition that a significant number of patients are injured in the course of medical treatment by medical intervention. Furthermore, there are indications that providers, in more cases than they are likely to admit, offer the public services of less than acceptable quality. Finally, if the study commissioned by H.E.W. ${ }^{2 \pi}$ is at all representative, a substantial portion of

a prepayment plan. Faltermayer, Better Care at Less Cost Without Miracles, FORTUNE 80,126 (Jan. 1970). Obviously, the observation that prepaid plans may underutilize surgery is a relevant, though not a controlling, consideration.

Dr. Crile also cites examples of incentives for the performance of more radical operations where simpler ones would suffice. Crile, supra, at 32. It is not uncommon in the United States to remove thyroid nodules by surgery rather than doing a needle biopsy to clarify the diagnosis. Thyroid cancer is one of the rarest causes of death by cancer while five to ten percent of all older women have lumps in their thyroids. Id. The delayed conversion of surgeons to simpler forms of breast surgery that avoid radical mastectomies is another example cited. Id. This radical procedure fell from favor in Europe and Canada prior to its demise in the United States. Thus, the subtle but substantial influence of fee-for-service systems over medical decisions again appears to indicate deviation from an appropriate standard.

Finally, Dr. Crile discusses examples of difficult and dangerous surgical procedures which, uulike routine operations, require esoteric skills. Id. at 35. The mortality rate from one of these operations, radical resection of cancer in the pancreas, varies significantly according to the physician performing the procedure. In the hands of speciahists with an interest in the disease, chances of dying from the operation itself are less than seven percent. In the hands of a generalist, the mortality rate averages thirty-two percent and ranges up to forty-six percent. Id. If a specialist is available, is it reasonable for the generalist to proceed?

Cardiovascular teams inight provide another example. It has been reported that a team must operate at least once or twice a week, with daily frequency preferred, to maintain optimal proficiency. Surgery Study Group, Inter-Society Comm'n for Heart Disease Resources, Optimal Resources for Cardiac Surgery, 44 Circulation A-221, A-223 (1971). If studies were to show that operation times were reduced and patient survival rates improved the more frequently a surgical team was employed, what would the prudent person conclude as to the appropriateness of using the under-employed team in noneniergency cases?

25. See Subcomm. on OVersight \& Investigations, supra note 23.

26. For a general historical treatment of the development of the negligence action as a narrowing of the basis for imposing civil liability, see James, Analysis of the Origin and Development of the Negligence Action, in DEPARTMENT OF TRANSPORTATION, Automobile InsURANCE ANd COMPENSATION Study 35 (1970).

27. See text accompanying notes 10-19 supra. 
medical injuries can be related to deviations from accepted standards of care.

If the H.E.W. percentages are used to calculate size estimates for the various categories, the results are staggering. ${ }^{28}$ Of the 2.6 million estimated annual iatrogenic injuries, eighteen percent, ${ }^{29}$ or 468,000 , would be classified as serious perinanent injuries and another thirty percent, ${ }^{30}$ or 780,000 , would be major teinporary. If the twenty-nine percent possible neghigent causation ${ }^{31}$ is applied in turn to these results, there would be a basis for 135,700 malpractice clains requesting coinpensation for serious perinanent injuries or deaths and 226,200 seeking damages for major temporary ailments against health care providers. Moreover, these projections assume that patients with minor injuries do not sue.

\section{Claim Frequency}

Information available on reported malpractice clanns indicates that the number of clains pursued is far less than the above estimate of potential clains. The H.E.W. survey estimated that 13,000 files were closed in 1970. Of these, 7,900, or sixty percent, were based on formal claim allegations and 5,100 on incident reports froin insureds. These 13,000 files were generated by 11,739 occurrences, eighty-two percent of whicll resulted in a claim against only one insured. ${ }^{32}$

Of the 5,100 files based on incident reports, only 1,400 , or twentyeight percent, were closed with payment. Of the 7,900 files based on formal clain allegations, 4,000 , or slightly over fifty percent, resulted in

28. Extrapolation of the H.E.W. study results, which are based on a small sample of files from two hospitals, admittedly does not produce highly reliable statistical estimates. However, given the corroboration from other studies on the magnitude of the injury universe, see notes 17-18 supra, the resulting figures become reasonable. The internal distribution as to negligent causation or severity of mjury is not as creditable, yet even here it must not be assunied that the estimates are invalid. If the negligence estimate were correct, it would mean that at least ninety-eight percent of discharged patients received adequate care by legal standards. The principal conclusion is that the number of possible claims is very likely mucli greater than the number of suits filed by attorneys, a conclusion supporting the assertion that frequency could continue to increase at a steady pace.

29. See text accompanying note 14 supra.

30. See text accompanying note 14 supra.

31. See text accompanying note 15 supra.

32. S. Dietz, Final Report: The Study of Medical Malpractice Clanms Closed IN 1970, at 80 Table IV-1, 82 Table IV-2 (1973). (An interim report of this study is in the Medical MaLPRACTICE REPORT Appendix 1-25.) The number of imsureds per claim file was strongly correlated with payment patterns. Only twenty-three percent of files closed with payment of $\$ 100,000$ or more involved one insured. 
payment. The paid-to-closed figure for both categories combined was 41.5 percent. $^{33}$ The claim study estimated that 10.6 percent more claim files were opened in 1970 than were closed. ${ }^{34}$ Applying this percentage, 14,375 claim files were believed to have been opened in 1970. Through the use of linear extrapolation, which assumes a constant rate of increase from one year to the next, the number of files opened froin 1971 to 1975 may be calculated at $15,900,17,600$, $19,500,21,500$, and 23,800 , respectively.

The Insurance Services Office (ISO) data on plyysicians and surgeons for recent policy years indicates that there has been an escalation in the rate by which the frequency of incurred claims is increasing (Appendix I). The armual increases between the latest three years of available data for physicians and surgeons have run sixteen, thirty, and twenty-eight percent respectively between policy years 1970-71, 197172 , and 1972-73. ${ }^{35}$ Based on a curve of best fit, ${ }^{36}$ the ISO calculated

33. Id. The percentage of claims closed with payment is affected by the insurers' guidelines for establishing a claim file. For instance, insurers underwriting medical associations, where efforts are made to encourage reporting of incidents and where every incident report results in the opening of a claim file, may close only twenty to twentyfive percent of all claim files with payment. However, if incidents which do not becone formal claims are omitted from the denominator, the paymeut percentages reach the forty- to fifty-percent range. Likewise, carriers that establish claims only when they expect an actual payment to be made, regardless of the source of the report, inay close sixty percent of their files with payment. Using H.E.W. data, the author calculated that 1.40 claims were paid per 100 physicians in 1970 . Calculations on other data bases produce an estimated paid claim frequency of $1.34,1.55$, and 2.20 per insured physician for equivalent time periods. Author's Survey of Professional Liability Insurance Companies (unpublished research done by Myron F. Steves, Jr., in preparation for his Ph.D. dissertation being completed at the University of Pennnsylvania). The data was gathered and updated between 1972 and 1975. The individual carrier is not identified by nane due to an agreeement made at the time of data collection.

34. Medical Matpractice Report 7 Figure 1.

35. Data for 1974 will not be available until the spring of 1976 because of the bureau's policy year reporting system.

36. The best known method of fitting a line to a set of data points is that of least squares. It is the line where the sum of the differences between the observed data points, in this case the frequency of claims per 100 physicians per year, and the estimated points is minimized. Linear lines of best fit assume a constant increase in slope. When it is not beheved that a straight line will fit a set of points satisfactorily because of the nonlinearity of the relationship, a simple curve or exponential line may yield a more satisfactory fit. The frequency of malpractice claim reports is such that a curvilinear line appears to provide a better basis for estimation than a linear one. Linear trends, however, provide couservative estimates as well as calculations that are nore easily understood by the regulators who must approve rate filings. See P. Hoel, INTRoduction to Mathematical Statistics 169-75 (1966). See also N. Downie \& R. Heath, Basic Statistical Methods $172-73$ (2d ed. 1965); B. Lindgren, Statistical THEORY 294-300 (1962).

The Insurance Services Office is a statistical agent and rating bureau for the large 
a trend factor on claim frequency of +12.1 percent per annum for use in its 1975 rate filings. ${ }^{37}$

ISO data for hospitals indicated a trend factor of +12.2 percent also based on a curve of best fit. ${ }^{38}$ The increases between the last four available policy years were $13.7,14.6$, and 27.4 percent, respectively (Appendix II). A hospital insurer, not reporting to the bureau, experienced stable frequencies from 1966 to 1970 with an upsurge in the range of fifteen to eighteen percent in the next three calendar years, and a jump of thirty percent in the first part of $1974 . .^{39}$

Another carrier with a significant volume of doctors reported increases from eight to ten percent in the late sixties and early seventies. However, 1974 showed an increase of twenty-five percent. ${ }^{40}$ One insurer with a book dominated by Class I and II physicians ${ }^{41}$ experienced frequency increases of 15.7 percent, 28.4 percent, and 68.3 percent between policy years 1971-72, 1972-73, and 1973-74, respectively. ${ }^{42}$ A specialty carrier with a stable book of business writing in an area outside the nation's trouble spots reported a seventy percent increase in the first part of 1974 over 1973. Final results lowered the initial estimate but the increase in frequency still exceeded forty percent. $^{43}$

A county inedical society survey showed an increase in doctors named in claims of over sixty percent per annum from 1969 to $1974 .{ }^{44}$ The latest yearly increases were less than the average but still in the thirty percent range. ${ }^{45}$ In Cook County, Illinois, malpractice suit filings

multiple-line stock insurance companies as well as for a number of other carriers. ISO reporting companies write a large percentage of the professional liability coverage in the country. The data in the review is based on approximately forty percent of the physician exposure in the United States.

37. Insurance Services Offici, 1975 Review of Physicians and Surgeons Professional Liabitry Insurance, Exhibit 2, Sheet 2, reprinted in Technical Appendix 568, and Exhibit 5, Sheet 5 (Apr. 18, 1975).

38. Insurance Services Office, 1975 Review of Hospital Professional LiaBIIITX INSURANCE, Exhibit 2, Sheet 2, and Exhibit 4, Sheet 5 (June 12, 1975).

39. Author's Survey, supra note 33.

40. Id.

41. Class I and Class II are general practitioners or internists who perform little or no surgery, and who thus have minimal exposure to extremely large malpractice claims. For a discussion of the ISO classification scheme for medical professionals, see Kendall \& Haldi, supra note 1. See also Hearings on S.482, S.215, and S.188 Before the Subcomm. on Health of the Senate Comm. on Labor and Public Welfare, 94th Cong., 1st Sess. 537-39 (1975).

42. Author's Survey, supra note 33.

43. $1 d$.

44. Id.

45. $1 d$. 
were up twenty percent in the first half of 1975 . Between 1973 and 1974, filings had increased 56.7 percent. $^{46}$ In a court docket survey conducted by a physicians committee from several counties in Michigan, malpractice suits filed increased 193 percent from 1970 to 1974, and the year 1974 showed an increase of 61 percent over 1973.47

\section{Claim Severity}

The concern of both providers and insurers over the increased frequency of claims has been heightened by an increase in claim severity. According to the H.E.W. report, the average paid claim cost was $\$ 10,600$ in 1970 for all providers combined. ${ }^{48}$ However, this average increases by fourteen to fifteen percent per annum on a total limits basis if ISO data are used to calculate a trend. If paid losses are broken down by layer, total payinents below $\$ 5,000$ per claim have increased froin five to eight percent in recent years. Payments below $\$ 25,000$ have increased in the ten- to twelve-percent range, while payments in excess of $\$ 25,000$ have posted increases exceeding twenty percent. ${ }^{49}$

The latest trend factors employed for purposes of calculating the ISO rate revisions for 1975 were 10.2 percent for limits of $\$ 25,000 / 75$,000 and 14.7 percent for total limits based on lines of best fit. ${ }^{50}$ Another program had a long-term linear trend of 10.2 percent, moving to 11.8 percent if years corresponding to the ISO calculations are used. The latest years available, which do not include 1973 or 1974, indicated increases of twenty-four percent. A third carrier reported se-

46. Relevant Ramblings, Cook CounTY JURY Verdict ReP., Apr. 11, 1975, at 1.

47. Physicians' Crisis Comamittee, Court Docket Survey 8 (1975). See Altman, Study Finds Malpractice System No Service to Public, N.Y. Times, Aug. 3, 1975, $\S 1$, at 41 , col. 5 .

48. S. DiETZ, supra note 32 , at 80 . A paid claim average excludes from the denominator all claims closed without payment of indemnity and includes only indemnity payments in the numerator. The $\$ 10,600$ is an average for all providers. In general, physicians and surgeons have higher average and median amounts paid on their behalf than other providers. Hospitals follow this trend, partly because many cases arise out of their hotel functions, which do not imvolve the same risk of serious injury as does the specialized care rendered by physicians. Nurses aud pharmacists have the lowest amount paid on their behalf; the H.E.W. study found no payment in excess of $\$ 4,000$ for this category of provider. Id. at 108.

49. Author's calculations based on ISO rate reviews issued from 1967 to 1975.

50. Technical Appendix 567. Corroborating the ISO trends, one insurer incurred an average yearly increase im paid losses of 12.7 percent from 1964 to 1973, with years corresponding to the ISO figures indicating an increase of 13.7 percent per annum. The years 1971 to 1973 showed an increase of 25.3 percent. The jump between 1973 and 1974 , not included in these trend calculations, exceeded forty percent. Author's Survey, supra note 33. 
verity increases on an annual basis ranging from ten to sixteen percent in recent years. ${ }^{51}$

The mean value of dollar awards escalated from $\$ 65,000$ in 1965 to the $\$ 300,000$ range in 1973 and $1974,,^{52}$ and there have been at least twenty-five settlements or awards in excess of $\$ 1$ million from 1968 to the end of 1974, most of these im the last two years. Eighteen of these were in California, only five of which were recorded prior to March, 1973. If settlements and awards in excess of $\$ 300,000$ are tabulated in California, excluding million-dollar awards, three were made in 1969, five in 1970, nine in 1971, thirteen in 1972, twenty-four in 1973, and twenty-mine in 1974. Prior to 1973, seventy-five percent of these payments were the result of verdicts. With the pattern of recovery established, however, sixty percent of the high payments in 1973 and 1974 were out-of-court settleinents. ${ }^{53}$

The expected annual increase in prennium costs for medical professional hability insurance can be estimated by combining the frequency and severity trends observed. The combined trend of the ISO on this basis is 23.6 percent per annum for losses at or below the $\$ 25,000 / 75$,000 level, ${ }^{54}$ while the total limits trend factor would be 26.4 percent. ${ }^{55}$ This figure is similar to the estimate made in a recent report to the Auditor General in California indicating an expected clain cost trend of 27 percent. $^{58}$ At this rate of increase, prennums would double every three years. ${ }^{57}$

51. Author's Survey, supra note 33.

52. The Doctor's New Dilemma, Newsween, Feb. 10, 1975, at 41. The article stated that the quoted figures excluded awards over $\$ 1$ million, but a conversation with Jury Verdict Research, Inc., revealed that these large awards actually were included. The basis for these figures is not a total sampling of all verdicts but only a tabulation of those reported or discovered by Jury Verdict Research.

53. The figures in text were obtained through the author's tabulations over the last several years from data published in Professional Liabinity Newsletter (D. Rubsamen ed.). These trends are not confined to California. One coinpany writing nationwide, excluding New York and California, estimates that thirteen claims in excess of $\$ 100,000$ arising from 1972 occurrences will be settled. Estimates for 1974 and 1975 are sixty and 190, respectively. Escess Claims Rising Rapidly, Malpractice Digest 6 (Mar./Apr. 1975, St. Paul Fire \& Marine Ins. Co.).

54. Technical Appendix 567. With respect to professional hability insurance limits, the dollar value before the slash is the amount for which the insurer is liable per claim; the value after the slash is the aggregate of the carrier's hability for any one policy year.

55. Id. at 568 (Total limits trend calculated by author).

56. Interim Report to the Auditor General: State of California, Concerning Medical Malpractice Insurance Study 3 (Sept. 1975).

57. In INTERIM REPORT, supra note 56, the investigators concluded that the "current malpractice crisis has been caused in part by poor pricing by the insurance industry, for premiums have increased erratically while claim cost increases have been relatively steady." Id. at 1 . With respect to the ISO filings, the price level for basic limits has 


\section{Premiums as a Percentage of Expenditures ON Health CARE}

Escalating malpractice premiums, attributable in large part to the increased frequency and severity of claims, have always been vital to providers concerned with their professional liability exposure. However, broader social interest in the resolution of medical malpractice insurance problems has developed only recently, for until the last two years insurance costs were not significant in terms of total national expenditures on liealth care. In 1970, the H.E.W. Commission estimated that $\$ 300$ million in premiums were paid by health care providers. This figure represented less than one half of one percent of the $\$ 75$ billion expended on health care during that year. ${ }^{58}$ According to this author's estimates, the same statistic for 1974 was only a little over one half of one percent. Since then the situation has changed rapidly. Malpractice cost will represent one percent of the health care costs in 1975 and 1.5 percent in 1976. By 1980, this percentage could exceed 2.5 percent. ${ }^{59}$

While premium costs are increasing significantly over historical levels, medical liability exposure still does not appear significant when coinpared with total health care expenditures. ${ }^{60}$ These figures, how-

increased 6.8,14.1,11.8, and 8.3 percent for the calendar years 1970 to 1973 for physicians. Hospital premiums increased 15.2, 9.9, 8.4, and 0.4 percent during the same four year period. In 1974, physician premiums jumped 52.5 percent and hospital premiums 49.6 percent. The 1975 indicated increase for physicians was 142.9 percent, with hospital premiums requiring a similar adjustment. Changes in the imcreased limit factors have exhibited the same trend. Limits of $\$ 100,000 / 300,000$ could be purchased for a factor of twenty percent of the basic $\$ 25,000 / 75,000$ premium up until 1968. Steves \& McWhorter, supra note 1, at 227 Table IV. In 1969, twenty-five percent was required. From 1970 to 1974, twenty-eight and thirty-two percent were required for physicians and surgeons respectively. In the fall of 1974 , the percentages were forty-nine and fiftytwo. The 1975 filings require seventy-four percent for physicians and seventy-seven percent for surgeons. Id.

The current price level changes are catch-up increases for previous years. However, given the magnitude of these increases, 1976 rate revisions may very weil be nouninal, regardless of the long range trends in frequency and severity. Providers, regulators, and insurers alike are only beginning to realize the necessity of increasing premiums to reflect statistical trends before the data on recent losses matures.

58. Medical Malpractice RePort 12n.5.

59. Steves, supra note 1 , at 215 . The 1974 fignre is based on a premium estimate of $\$ 500$ million and expenditures of $\$ 94$ billion. The 1975 figure is based on premiums between $\$ 1$ billion and $\$ 1.2$ billion and expenditures of $\$ 115$ billion; the year 1976 is based on figures of $\$ 2$ billion and $\$ 129$ billion. The 1980 figure assumes that medical costs increase ten percent per annum while malpractice premiums go up twenty-five percent per year from 1976 to 1980 .

60 . In $1974, \$ 14$ billion was paid to carriers for insurance to cover automobile accident liability. See Insurance Information Institute, Insurance Facts 12 (1975). 
ever, ignore the distribution of premium and income within the health care sector of the economy. Because of differences in exposure to losses from liability claims, seventy percent of the premium dollars paid are contributed by plysicians and surgeons, ${ }^{61}$ while only twenty percent of total expenditures on health care are made in payment of physician services. ${ }^{62}$

Similarly, the percentage of gross income expended by physicians for professional liability insurance, when viewed on an overall basis, is relatively small. In 1970, 1.34 percent of physicians' gross imcome was spent for professional liability insurance. ${ }^{63}$ By 1974, this percentage had risen to 1.89 percent, and the estimates for 1975 and 1976 are 3.68 and 6.68 percent, respectively. ${ }^{64}$ If malpractice premiums were spread evenly over all medical specialties, even the projected figures would not disrupt the lealth care dehvery system. However, premiums are not spread uniformly over all practitioners. ${ }^{65}$ The forty percent classified as surgeons pay seventy-five percent of the insurance premiums, and if Class III general practice surgeons, oplithalmologists, and proctologists are excluded, fifty-five percent of the premium is paid by twenty-five percent of the plysicians. ${ }^{06}$

Depending on the estimate of the aggregate personal expenditures for automobiles, this means that from ten to fifteen percent of the direct costs of the private passenger transportation system are related to automobile accidents. Sixty percent of these premiums were for third-party liability. Id. The total economic cost of auto accidents in 1973, of course, was much higher than those losses covered by insurance. The Insurance Information Institute estimates the latter figures at $\$ 30.4$ billion. Id. at 50. Although provider liability insurance payments have increased dramatically when expressed as a percentage, the direct cost of insuring the medical malpractice exposure is substantially under the cost of insuring the hazard of automobile accidents.

61. The Author's Survey resulled in an estimate of slightly more than seventy percent. The H.E.W. study by Kendall and Haldi derived an estimate of slightly less than seventy percent for 1970. Kendall \& Haldi, supra note 1, at 509 Table III-6.

62. In fiscal 1973, physician services accounted for 18.4 percent of total national health expenditures. OfFice of Research \& Statistics, Social Security Admin., ReSEARCh AND Statistics Note 1, at 3 Table 2 (Feb. 19, 1975). In 1970, the figure was 19.6 percent, and in 1960 it was 21.1 percent. Id. at 7, Table 4. See Bureau of THE Census, U.S. Dep'T of Commercis, Stattstical Abstract of the Untred States 70 Table 101 (96th ed. 1975). See also Worthington, National Health Expenditures 192974, 38 Social Security Bull. 3 (1975).

63. Steves \& McWhorter, supra note 1, at 232 Table XI. The calculations were based on fiscal year figures obtamed from the Social SeCurITY BULletin, 1955 to 1974.

64. Steves \& McWhorter, supra.note 1, at 232 Table XI.

65. Current ISO class differentials have a spread of eight to one. Id. at 226 Table III. Sixty percent of all physicians are in Classes $I$ or II, with most of these in Class I. Many surgical specialists are charged five times the basic rate, while obstetrician/ gynecologists and plastic surgeons are assigned a factor of six. Neurosurgeons, orthopedists, and thoracic and vascular surgeons are assigned the highest multiple, eight. 
The effect of this skewed premium distribution is related to the gross incomes of the individual medical specialties. According to the American Medical Association's seventh periodic survey of physicians, the average malpractice expense was less than two percent of gross income and less than five percent of total professional expense. The general surgeons' hability premiums equaled 2.4 percent of gross imcome and 7.4 percent of professional expense. For obstetrician/gynecologists the percentages were 3.0 and 7.9. Anesthesiologists, however, paid 4.5 and 18.9 percent of income and expenses, respectively, for their insurance protection. At the other end of the scale, internists paid 1.0 and 2.4 percent while pediatricians paid 0.9 and 2.1 percent. ${ }^{67}$

Variations in geographical ratings compound the skewed distribution based on specialization. While location affects physician income, its impact on premium levels is most significant. The AMA survey indicates that the mean burden of premiums related to gross income varies considerably by state. In 1970, statewide average premiums for malpractice insurance were 3.53 percent of gross income in New York, 3.25 percent in California and 2.06 percent in Florida ${ }^{68}$ Pennsylvania, Ohio, and Connecticut averaged 1.28 percent, while Mississippi, South Carohina, and New Hampshire were at the low end of the range with $0.86,0.78$, and 0.69 percent respectively. ${ }^{69}$

The latest ISO rate level recommendations corroborate the pattern observed in the AMA survey. The countrywide average premium for $\$ 25,000 / 75,000$ limits indicated in the 1975 rate review was $\$ 984$. The range, however, stretches from $\$ 273$ for New Hanıshire to $\$ 3,348$ for California, or from .27 to 3.40 times the average. ${ }^{70}$ The median premium of approximately $\$ 745$ is lower than the average. Based on this inedian base premium, standard ISO class differentials, and excess limits factors, Class I physicians would pay $\$ 2,026$ for $\$ 1$ million $/ 3$ million in coverage while Class VII surgeons would pay $\$ 16,569$ per

66. Author's calculations, based on figures in Insurance Services OfFice, PhysiCIANS AND SURgeons-Differential Study 1975 (Apr. 28, 1975).

67. The percentage calculations in the text are based on data in the AMA's 1973 Profiles of Medical Practice, AM. Med. Ass'N, Profiles of Medical Practice (1973), and corroborated by data abstracted from the AMA Seventh Annual Survey, prepared by the Department of Social and Economic Research of the AMA's Center for Health Services Research and Development and provided to the author on special request.

68. AMA Seventh Annual Survey, supra note 67.

69. Id.

70. The figures in text are the author's calculations, based on data from INSURANCE Services OFFICE, supra note 37. The median premium is the median state Class I premium for basic limits (Wisconsin $\$ 739$ and Minnesota $\$ 752$ ). 
annum. The range for the top-rated surgeons based on ISO filings would be from $\$ 6,334$ in New Hampshire to $\$ 77,674$ in California. ${ }^{71}$

The uneven distribution of the premium burden by specialty is aggravated by other characteristics of the physician and type of practice. Physicians practicing alone earn less than average incomes while partnerships and informal associations earn greater than average incomes. ${ }^{72}$ Furthermore, physicians in the earher and later years of practice earn less than practitioners in their middle years, a phenomenon not unrelated to the volume of services rendered. ${ }^{73}$ Since premiums tend to be uniform within rating classes, the older physician in solo practice may well be paying an even larger percentage of his gross income for premiums than the averages indicate. If gross income is low and premium expense high because of specialty, as in the case of anesthesiologists, ${ }^{74}$ the collateral effects of practice organization and age, as related to the volume of services rendered, may place the physician in an extremely vulnerable position. At this poimt, premiun levels may result directly in physicians' decisions to change, modify, or abandon their practice. ${ }^{75}$

71. Author's calculations. The premium for the Class VII surgeon in California is several times that which is suggested as an adequate rate by the carriers active in that state. However, the ISO premium level assumes a .667 permissible loss ratio and .333 for other expenses and profit. The net rate for losses would be $\$ 51,808$. Further, the differentials between classes has not been as wide in parts of Califormia as it has been in other parts of the country, a factor which would further reduce this figure. Also, the fact that the exposure reported to ISO is not a large percentage of the writings in California and may be weighted with physician, in contrast to surgical, exposure might also have an impact. Finally, if a twenty-five percent factor were apphed to account for investment income, the ISO premium approaches the upper limit of what has been suggested with respect to prices in the California market. Since the premiums charged in the state have been understated historically, it is hard to disiniss the "modified" ISO figure as having no basis. Even if it is assumed that the 1976 price for the highestrated specialist should be $\$ 25,000$, it will be in the range indicated as required by the ISO between 1978 and 1980 , depending on what modification is made to the $\$ 77,674$ figure.

72. The average gross income of solo practitioners in 1973 was estimated at $\$ 78,789$, while two-person groups averaged $\$ 99,135$ per physician. The average for all practitioners was $\$ 83,969$. Centrir for HeAItH Services Research aNd DeVELOPment, Am. Med. Ass'n, Profile or Medical Practice 1974, at 195, 204.

73. Center for Health Services Research and Development, supra note 72, at 197-200. Income, age of practitioner, and average number of office visits are strongly correlated.

74. See text accompanying note 67 supra.

75. Although there is relatively little formal documentation of the phenomenon, there is evidence that premium levels do affect practice decisions. As an insurance broker dealing in this area, the author would estimate that at least a dozen such cases have come to his attention in the past year. The most frequent example is the Class III General Practice Surgeon who derives approximately ten percent of his income from 


\section{Concentration on Malpractice Claims}

The ways in which price, quantity, and quality of health care services are affected by concerns over legal liability or the conventional methods of insuring this liability are not well documented. However, there is little doubt that providers, particularly pliysicians, perceive themselves to be in a disadvantageous position and are seeking to improve their present situation. Individual proposals, designed either to affect the pricing and availability of malpractice insurance or to alter or narrow the civil liability of providers, are continually being advanced. ${ }^{76}$ Unfortunately, most of the propositions concentrate on malpractice claims. While claims liave a direct cost cliargeable to pliysicians and other health care providers, they represent the smallest percentage of medical accidents. ${ }^{77}$ Iatrogemic injuries and substandard care which do not result in claims should be of more immediate concern to provider and consumer alike. Nevertheless, economic incentives are sucli that a disproportionate share of the attention of those best able to control the quality of medical care is directed toward claim reduction.

This phenomenon is tied directly to the reliance of our economic and social structure on the legal concept of negligence, which holds the actor personally responsible when deviation from an acceptable standard causes harm. The actor is responsible for his actions only if they result in a finding of wrongdoing. ${ }^{78}$ As a practical matter, the actor is not liable for all negligent acts, for the evidentiary burden is on the injured party, and the actor is legally responsible only when the person damaged can prove by a fair preponderance of the evidence that the actor owed him a duty of care, departed from that duty, and damaged his interests as a direct result of that departure. ${ }^{79}$ Application of negligence principles to the dehivery of health care services means that providers are financially liable for only a small portion of the inedical accidents which in fact occur.

A continued focus on claims may result in dilution of the quality

surgery. The effect of this activity on his insurance premiums is such that his surgical practice generates little or no net income. Cf. Brook, supra note 5, at 1212-13. The author is aware of another situation where a surgeon specialist shifted to a inedical practice five years prior to the normal retirement age. Part of the reason was the difficulty of paying a full surgical premium while gradually restricting surgical activity.

76. For a discussion of recent state legislative attempts to meet the immediate problems created by the current malpractice insurance crisis, see Comment, An Analysis of State Legislative Responses to the Medical Malpractice Crisis, 1975 DukE L.J. 1417.

77. See notes 20-47 supra and accompanying text.

78. See James, supra note 26, at 51-56. See generally W. Prosser, HaNdBook of THE LAW OF TORTS 143-179 (4th ed. 1971).

79. See generally C. WASMUTH, supra note 6 . 
control function of the present liability system, since only those injuries with a high likelihood of producing malpractice claims of significant value becoine of direct economic importance to the provider. Furthermore, since the frequency of clains is low compared to the total voluine of services rendered, the cost of focusing on a known hazard may not be financially justified. Because of the exposure base used for rating professional liability insurance, even individual practitioners and health care providers who follow exacting quality control procedures are not likely to receive any direct financial benefit for their efforts.

Concentration on the claim universe to determine both the medical and noninedical aspects of insured malpractice losses is not without reward, lowever. Studies of the types of claims alleged, the severity of injuries incurred, the characteristics of claimants and defendants, and the effect of attorney representation supply useful information to providers of health care. ${ }^{80}$ For example, inspection of claim files may reveal the hazards of failing to establish rapport with patients, of practitioners commenting on work done or results obtained by colleagues, and of the risks involved in using certain collection procedures. Improvernent in these areas could result in the filing of fewer claims when injuries occur. Indeed, fewer injuries might occur if provider-patient relationships were warmer and medical personuel were more aware of the complaints of their clients. Nevertheless, if from the standpoint of the general econoiny, as well as that of individual patients, injuries are by far the larger and more costly occurrences when compared to claims, it would appear proper to concentrate on the former in designing a system to monitor the quality and quantity of services rendered, even though some benefit may be gleaned from attention to the latter. Furthermore, claims by definition involve the possibility of litigation, a factor not conducive to frank and open discussion of mjury prevention.

\section{EMPHASIS ON INJURIES}

One alternative to concentration on claims is to place the direct cost of a much larger subset, that of injuries occurring in the course of medical treatment, on the shoulders of healtl care providers. Under one such proposed systein, termed Medical Adversity Insurance, ${ }^{81}$ the relative avoidability of an injury, not negligence, is the criterion for

80. See, e.g., Medrcal Malpractice Report; Medical Malpractice Report Appendix; Mills, Medical Lessons from Malpractice Cases, 183 J.A.M.A. 1073 (Mar. 1963).

81. See generally Havighurst \& Tancredi, supra note 18. See also Havighurst, "Medical Adversity Insurance"-Has Its Time Come?, 1975 Duke L.J. 1233. 
designating an adverse medical event as compensable. The cost burden is placed on the provider best able to effect an improvement in quality control and a concomitant reduction in the frequency and severity of injuries. The example of hepatitis incident to transfusion illustrates the type of event that this system would compensate as well as the magnitude of the financial incentives that would be involved. ${ }^{82}$

Despite the conceptual appeal of a system that einploys financial incentives and market mechanisms to encourage injury prevention, the likelihood that such a scheme would be accepted by government and the special interests involved is remote. The program makes significant implicit costs explicit, a violation of the laws of practical pohitics.

The alternative means of achieving control of the quality and quantity of inedical services is through regulation. The principal source of this type of control is the self-regulation imposed by the providers themselves, simce the good intentions and moral character of those engaged in the healing arts are primary. The values of the providers find formal expression in the bylaws of medical societies, requirements of organizations like the Joint Commission for the Accreditation of Hospitals (JCAH), and laws governing licensing and medical practice. $^{83}$

Third-party payors, originally Blue Cross and Blue Shield and private health imsurers, and now the government-sponsored Medicare and Medicaid plans, have reinforced incentives to comply with acceptable inedical standards by insisting upon functioning utilization review, medical audit, and tissue committees in the hospitals they reimburse. ${ }^{81}$

82. See note 19 supra. The state of the art does not allow detection of the hepatitis virus in whole blood in most circumstances. However, the contamination rate of paid donor blood is known to run higher than that of voluntary donor blood, perhaps ten times as high. See Franklin, Tort Liability for Hepatitis: An Analysis and a Proposal, 24 Stan. L. Rev. 439, $444-45$ (1972). Despite this statistic, twenty-five percent of all transfusions in this country employ the more hazardous product. Id. at 441 . Although the good will and moral integrity of providers is on the side of reducing reliance on paid donor blood, substantial economic incentives are not. Even though no court has accepted the doctrine that use of paid donor blood is negligence, einphasis on injury reduction suggests that it might be appropriate to apply a concept of enterprise liability if harm is caused when hepatitis is transmitted by this category of blood.

83. See D. HARNeY, Medical Malpractice 122-30 (1973) (use of accreditation criteria as medical standards). See note 7 supra and accompanying text.

84. Utilization review usually requires that the need for continued patient care be certified at regular intervals once a patient's length of stay exceeds some normative criterion. Medical audits are random reviews of physician services rendered in hospitals to verify that they are of appropriate quality. Tissue committees monitor the results of surgery, and pathology reports indicate whether removed tissues are normal or abnormal. If a surgeon's percentage of either falls outside an acceptable range, a inore comprehensive review of his surgical practices is undertaken by the tissue committee. 
The 1972 amendments to the Social Security Act, ${ }^{85}$ requiring the creation of Professional Standards Review Organizations (PSROs), ${ }^{86}$ have expanded the concepts of commumity- and hospital-based peer review. Concerned with review of care financed by federal funds, the PSRO system will provide decentralized control of the quality and quantity of the services rendered by institutional as well as individual providers. The initial concentration will be on utilization of hospital facilities and, to the extent possible, the PSROs will defer to hospital review committees where the activities of these committees are judged satisfactory by the new standards. The PSROs will have the power to withhold authorization for payment of health claims as an incentive for providers to render only necessary services of acceptable quahity. The organizations will also have the duty to disclose adverse decisions relating to providers, at least in the event of recurrent and flagrant violation of standards. Of equal, if not greater, importance, however, will be the dissernination of comparative information on the normal practices and standards of other providers both within and without the local organization. Combined with evaluative studies of the efficacy of particular procedures and the etiology of specific diseases, these methods of monitoring utilization should promote a better health care system. ${ }^{87}$

\section{FOCUSING LIABILITY ON THE HOSPITAL}

The existing regulatory system of controlling quahty of health care services and the general acceptance of negligence law limit the approaches one may take to resolve the current problems of malpractice litigation and medical malpractice insurance. However, it is possible to construct a system that anieliorates the problem of increasing premium costs and, at the same time, strengthens imcentives to prevent injuries. While hability insurance would not be the primary mechanism for providing quality control as in the medical adversity insurance program, it would be supportive of the regulatory structure.

The proposed concept would shift the legal liability exposure and the cost of insuring it from individual practitioners to institutional

85. Pub. L. No. 92-603, § 249F, 86 Stat. 1429 (codified at 42 U.S.C. $\S \S 1320 \mathrm{c}-1$ to $\mathrm{c}-19(1973))$.

86. The constitutionality of this PSRO program was upheld by the Supreme Court in Association of Am. Physicians \& Surgeons v. Mathews, 96 S. Ct. 388 (1975).

87. See generally Staff of Senate Comm. On Finance, Background Matertal Relating to Professional Standards Review Organizations (Comm. Print. 1974); Comment, PSRO: Malpractice Liability and the Impact of the Civil Immunity Clause, 62 Gвo. L.J. 1499, 1500-02 (1974); Note, Federally Imposed Self-Regulation of Medical Practice: A Critique of the Professional Standards Review Organization, 42 GEO. WASH. L. REV. 822 (1974). 
providers for incidents occurring within institutional settings. ${ }^{88}$ Thus, the liability and liability insurance premiun resulting from acts of physicians and surgeons would be transferred to hospitals, where seventyfive percent of all claims arise. ${ }^{89}$ The remainder of the exposure would be a non-hospital risk that could be insured by practitioners on an individual basis.

Although the concept is simple, the values of such a premium shift are numerous:

Distribution of Premiums. The premium burden of the professional liability exposure would inatch more evenly the expenditure patterns for health services in the economy. Hospital care expenditures are twice those for physician services. ${ }^{90}$ Assuming adjustment in charges by both providers, it is likely that inalpractice insurance preiniums would approach a proportional distribution with respect to gross revenue from services.

Continuity. The bulk of the premium expense would fall on lospital corporations, which have a mucl broader capital base and a inore rehable cash flow than the economic unit of physicians in solo or small group practice common in this country's health care delivery system. Institutional providers, both legally and structurally, can be expected to continue in existence indefinitely, for their operation and ability to pay premiums is not predicated on the good health or survival of any one individual.

Among other considerations, the contimuity of a corporate enterprise ineans that the insurance industry can approach coverage probleins with a broader range of techniques. For exainple, a "claims nade" policy form could be used without adversely affecting the interests or increasing the uncertainty that a particular imjury to a patient by a practitioner would be an uninsured loss. ${ }^{91}$

88. The Virginia Bureau of Insurance has proposed such a plan. BuREaU of INs., State Corp. Comm'n (Virginia), Medical Malpractice Insurance IN Virginia: The Scope and Severity of the Problem and Alternative Solutions $81-93$ (1975).

89. Rudov, Myers, \& Mirabella, supra note 14, at 1, 10. Figures in the seventy to seventy-five percent range are reported in other surveys; one early survey indicated that seventy-one percent of physician cases examined were related to occurreuces in hospitals. Sadusk \& Waterson, Professional Liability, 87 CaL. MED. 192, 198 (1957).

90. Of total health expenditures in 1973, 18.4 percent were for physician services and 38.6 percent were for hospital care. Office of Research and Statistics, supra note 62 , at 3, Table 2; see also Bureau of the Census, supra note 62, at 70, Table 101.

91. A "clainıs made" policy provides coverage based on the year in which a clain is first reported. An "occurrence contract" provides coverage based on the time of occurrence of the act giving rise to the allegation of negligence. See New Form of Malpractice Liability Coverage to be Offered to Doctors, Malpractice Digest 1 (Jan./Feb. 1975, St. Paul Fire and Marine Ins. Co.). One problem in the shift from an occurrence 
Premium Volume. The premium volume generated per risk by the proposed system, taken im conjunction with the consideration of continuity, would make experience and retrospective premium agreements more feasible. ${ }^{92}$ Use of very high deductibles, self-insured retentions, and aggregate excess insurance plans would become more practical. ${ }^{93}$ The expertise in risk management employed successfully in other industries would become more apphicable to the corporate entities providing health services.

From the marketing standpoint, increased premiums per risk, with less uncertainty in pricing, should encourage innovative thinking, if not outright competition, among insurers for this type of business. The great opportumities for momitoring and controlling the exposure insured would be an additional encouragement.

Exposure Basis. Insurers could experiment with exposure bases other than the individual doctor or the occupied hospital bed. Exposure might be tied more appropriately to the types of patients treated, the kinds of surgery performed, the number of anesthetics given, or any combination of these measures. ${ }^{94}$ Another possibility would be to tie the imitial premium to gross receipts. ${ }^{95}$

Among its other advantages, a hospital-based exposure system would mean that new practitioners, or practitioners who desire to restrict the quantity of services they render, could make a decision without

to a claims made form is how to insure against claims arising out of occurrences during the final year of a physician's practice.

92. See Roddis \& Stewart, supra note 22, at 1302-03.

93. A larger hospital paying a premium of $\$ 1$ million under the existing system might pay as much as $\$ 4$ million under the proposal suggested. At this level, retaining a significant deductible amount or a proportional share of all losses would provide incentive for risk control. Cf. Havighurst, supra note 81, at 1251 . One basis for this arrangement would be for the risk to retain the first $\$ 100,000$, or some other appropriate amount, of each loss as well as the excess over that figure up to a maximum amount. An insuring arrangement would be triggered when the aggregate of the losses in excess of $\$ 100,000$ was greater than a predetermined amount. The size of the retention would depend on the premium volume that would be generated on a straight insurance basis.

94. The California Hospital Associatiou program currently charges a rate per occupied bed, per outpatient visit, per emergency service visit (higher than outpatient rate), and a rate for each surgery (defined as one in which a general anesthetic is used), as well as charging a premium for the employed physicians. The concept proposed in text is designed to make such a system as refined as is practicable, assuming there is a relationship between the types of services rendered and exposure.

95. A gross receipts premium basis for rating physicians has been evaluated by $\mathrm{m}$ surers and regulators and rejected because of the fact that there is no direct correlation between income and exposure in the malpractice situation. 2 NAT. Ass'N INS. CommrsSroNERs Proc. 607 (1971). However, as a point of departure for general hospitals, the concept may be more appropriate. 
regard to the financial considerations posed by existing classification and rating procedures of insurers.

Effect of Premium Increases. Assuming premiums continue to increase, hospital providers would be in a better position to pass the costs through the systein than would the individual practitioner. Hospitals, with their detailed charge structures, could build in the additional expense with hittle distuption. With overhead already high, the relative increase in room rates or facility and procedure charges required would be less than the increase most physicians would be forced to charge. The increment per patient discharged, although readily identifiable, would not represent a significant portion of total charges to the patient. ${ }^{98}$ In addition, patients tend to be better insured for care rendered in a hospital setting. ${ }^{07}$

Furthermore, hospitals are generally remibursed on a cost basis for Medicare and Medicaid patients, ${ }^{98}$ as well as for service benefits provided under Blue Cross coverages in some jurisdictions. ${ }^{99}$ Such retrospective cost reimbursement contracts would automatically absorb premium increases, im sharp contrast with the practice prescribed for physicians which dictates billing on a fee-for-service basis only within the bounds of "usual and customary" rates. ${ }^{100}$ In the case of the various medical aid programs administered by state governments, payment schedules rather than custoinary fees are the norm. Such schedules are unlikely to respond to rapid increases in insurance costs as they affect particular specialties rendering particular types of services.

Incentive for Quality Control. The hospital and its medical staff would have increased incentive to control the quality of services. This incentive would result from several factors. First, the magnitude of

96. In Virginia, for example, it has been estimated that shifting the malpractice burden to hospitals would increase the daily per bed rate by only $\$ 1.20$. BUREAU OF INS., supra note 88, at 83-84. But see Hearings on S. 482, S. 215 and S. 188, supra note 41 , at 333 (testimony of HEW Secretary Weinberger); id. at 380 (statement by Alexander McMahon, Presideut of American Hospital Ass'n).

97. In 1973, only 11.4 percent of national expenditures on hospital care were handled through direct payments. OfFICE of Research AND Statistics, supra note 62, at 9, Table 5. In contrast, 36.4 percent of expenditures on physician services in the same year were in the form of direct payments. Id. at 8 , Table 5 .

98. For a discussion of the impact of cost reimbursement, see Falk, Financing for the Reorganization of Medical Care Services and Delivery, 50 MILBANK MEMORIAL FUND Q. 191 (1972).

99. In areas where Blue Cross plans provide health msurance for a large segmeut of the population, cost reimbursement is used rather than payment of charges. The fivecounty area around Philadelphia is one example.

100. See generally Blue Cross-Blue Shield of North Carolina, Usuat, CustomARY, AND REASONABLE: AN EXPLANATION FOR M.D.s (1974). 
premium volume would draw the attention of the medical staff, as well as the board of directors and administrative staff of the hospital, to the problems of claims and injury prevention.

Second, hospitals provide an independent basis for control and review of medical practice. Although the professional ethics of the providers and the requirements of third-party payors are obviously the primary impetus for effective control, the addition of a monetary incentive in the form of substantjal malpractice premiums would encourage these review boards to give additional attention to problem areas. If the premium were based on a per surgery or a per anesthetic charge, subject to modification for experience, imcentive to review both quantity and quality of services would be enhanced.

Third, the hospital would have an expanded opportumity to prepare a more sophisticated data base for medical injuries as well as for claims. The premium dollars paid by a single institution would justify research and development of a more elaborate quality control system that would integrate information either as yet uncollected or maintained separately by hospitals, physician committees, and insurance companies.

Fimally, the premium volume, combined with better information on the efficacy of various quality control procedures, might make it possible to provide direct econoumic benefits for alterations and improvements in standards, procedures, or methods of monitoring the quality and quantity of services rendered. Experience 1might indicate that, like fire insurance, debits and credits could be assigned for specific features of the health care system operation.

Professional Standards Review Organizations. Taken together, the advantages of the proposed system of centralizing hability exposure with respect to acts occurring within institutional settings support the goals and concepts proposed in the legislation establishing the Professional Standards Review Organizations. ${ }^{101}$ The proposed liability system provides additional imcentive for an evaluation of health care which has quality improvement as an objective, but, for very practical reasons, gives priority to control of the utilization of services. ${ }^{102}$

Alternative Compensation Plans. The hospital provides a better forun for experimentation with alternative methods of compensatimg

101. See text accompanying notes 85-87 supra.

102. The methods of evaluating quality of care are not as sophisticated as those for regulating the quantity of services rendered. Utilization review and tissue committee controls, for example, focus on the quantity of services. Utilization review, however, is a function of quality control because of the correlation between length of stays and complications of medical treatment. 
injured parties. For instance, if arbitration of claims is desired, patients, prior to entering the hospital, could be requested to agree to this method for resolving disputes. A provision for rescission of the arbitration agreement within thirty days of discharge would alleviate the probleins of adhesion. ${ }^{103}$ The hospital has advantages in the implementation of this arrangement that do not exist im a physician's office practice unless a large clinic is involved. Alternate methods for resolving patient dissatisfaction or of compensating some injuries without regard to fault could find a suitable testing ground under the proposed system.

Advantages in Litigation. If a case goes to trial, there is an advantage to health care providers in presenting a common defense. The surgeons, anesthesiologists and all the employees of the mstitution need not buy out of litigation by way of settlement for fear of being caught in a crossfire of accusations. Cases could be evaluated on their merits and arbitrary damage allocations according to availability of liability limits avoided. This unifying of defendant interests might work to the advantage of plaintiffs as well. Meritorious claims could be settled under circuinstances that might delay settlement if the interests of the defendants were separate. An example would be the situation where it is difficult to determine which act, in a series of mishaps, actually caused the injury ${ }^{104}$ or when settlement is not made promptly because of the reluctance of one of several defendants to settle.

Practitioners Liability. The renaining office liability of practitioners could be handled in many ways. One proposal would be to encourage the local societies or, perhaps, the national specialty associations to organize insurance programs. ${ }^{105}$ This structure might pronote a flow of inforination within specialties that would result in injury reduction for both hospital and nonhospital exposure. Nominal surcharges to premiuns for tabulation and commumication of information about injuries might be one way to encourage prevention. A single nationwide defense league might be feasible as well, with the hospital

103. The California Hospital Association, in cooperation with its legal counsel and the Farmers Insurance Group, applied such a procedure on a dennonstration basis in California.

104. See, e.g., Starr v. Fregosi, 370 F.2d 15 (5th Cir. 1966); Ybarra v. Spangard, 25 Cal. 2d 486, 154 P.2d 687 (1944).

105. Based on expected 1976 preinium levels, a level rated premium on the range of $\$ 1,000$ to $\$ 1,500$ would provide high limit protection for the physician's office exposure. A level rated concept becomes feasible because forty-eight percent of all claims filed against Class I physicians arise from events outside the hospital. For Class II doctors the same percentage is forty-six and for Class III it is thirty-two. For the surgical specialists the rates are in the ten- to fourteen-percent range. See S. DiETZ, supra note 32, at 103, Table VI-3. 
exposure eliminated from the base. In this way the national association could concentrate on a manageable subset of malpractice problems.

While physicians may welcome a shift of hability exposure and premiums to the institutional providers, they may well be concerned with the corresponding shift from practitioner independence to inore centralized institutional control. However, under the proposed system, the bulk of the actual supervision would continue to be exercised by the physicians theinselves through the medical staffs. The governing boards of the hospitals would have an imcreased imterest in seemg that the medical staff in fact performed its function. In light of the current judicial trends interpreting corporate liability, ${ }^{106}$ as well as the regulatory pressures exerted by PSROs, ${ }^{107}$ physicians will continue to be supervised more carefully and will lose some measure of independence regardless of the imsurance system employed. Thus, the proposed system does not break entirely new ground, and its overarching policy of quality patient service is one which all physicians should weigh against their concerns over inedical independence.

Institutional concern would center on the substantial financial burden placed on hospitals until charge structures and operating procedures could be appropriately modified. In contrast to this burden, individual providers would be seen as the beneficiaries of at least a short-term windfall. However, normal market pressures and negotiations between the two providers should resolve any significant mitial economic disturbances caused by the proposed plan. ${ }^{108}$ For example, in the imitial year physicians could contribute to a hospital premium fund an amount based on the proportion of hospital-based services rendered during the year to all services. This part of the total premiun could then be allocated to the specific institutions with which the practitioner was affiliated. ${ }^{109}$ In subsequent years, the contribution could be scaled down until the physician paid only for his office exposure.

106. See Mitchell County Hosp. Authority v. Joiner, 229 Ga. 140, 189 S.E.2d 412 (1972); Moore v. Board of Trustees of Carson-Tahoe Hosp., 88 Nev. 207, 495 P.2d 605 (1972), cert. denied, 409 U.S. 879 (1972); Darling v. Charleston Community Memorial Hosp., 33 Ill. 2d 326, 211 N.E.2d 253 (1965), cert. denied, 383 U.S. 946 (1966). See also D. RuBSAMEN, Hospital Corporate ResponsibILITY 11 (to be published).

107. See notes 85-87 supra and accompanying text.

108. It is possible that a premium sharing arrangement might be implemented as a permanent device for some of the smaller hospitals in rural communities.

109. The medical record abstracting systems employed by most hospitals routinely tabulate information on the number of surgeries by type for each physician. Medical services could be similarly tabulated on the number of admissions per physician. These data would be the basis for proration of a physician's premium in the first year or years of transition. 
Another possibility would be to shift the hospital exposure from an "occurrence" to a "claims made" form. ${ }^{110}$ This pattern of claim reporting would give the hospital several years to adjust to the new situation before the full impact of the shift in exposure was realized. ${ }^{111}$ Meanwhile, physicians could contribute the difference in their premiums, which resulted from exclusion of hospital exposure, to the surplus of one or more broadly based physician-owned or -controlled insurance companies suggested to handle the office exposure.

For the first few years after the transition, patients could expect fees for physician services to remain relatively constant. Gains from the changeover in hability exposure would offset the routine increases attributable to inflation. Interim price controls or procedures designed to nonitor provider income and expense could also be implemented on a short-term basis to stabilize profit margins during the transition period.

\section{CONCLUSION}

As the total cost of nualpractice has become an increasingly significant portion of health care expenditures, public interest in maximizing the benefits derived from premums paid has grown. Unfortunately, the existing pattern of imsuring against nedical malpractice does not meet these growing expectations of proper premium utilization. The premium burden falls on physicians organized in small econormic umits that carmot support proper quality control with information feedback. The individual practitioner's exposure umit allows for little pricing flexibility, resulting in almost no economic incentive to prevent injuries. While premiums tend to be uniform within medical specialties in a particular territory, irrespective of quality or quantity of service, the distribution of losses by specialty skews premiums in such a way that a growimg number of practitioners are finding the increased costs an unbearable financial burden. Thus, the hability system has often become counterproductive and has affected delivery of service without proper regard for the broader requirements of an optimal health care system.

What is needed is a system which supports the broader concept of control of injuries while readjusting the cost burden of malpractice claims. Shifting premium expense to the hospitals satisfies both these criteria. Premiun burdens would be placed where they could best be

110. See note 91 supra.

111. Data collected in the Author's Survey, supra note 33, indicate that clains might be expected on the following basis for physicians: first year, thirty percent; second year, thirty percent; third year, twenty-five percent; fourth year, ten percent; and fifth year, five percent. Patterns of claim reports vary by state; further, the dollar value of reports is not necessarily constant over all periods. 
borne and where mechanisms for quality control already exist. Making the hospital liable for services provided within its walls would shift a large amount of premium to one location where traditional insurance techniques are more easily applied and risk management more feasible. Finally, the residual office exposure would be such that any number of innovative methods could be implemented to insure the non-hospital risk as well as promote injury prevention.

While certain transitional problens cannot be wholly avoided, proper plarming and cooperation between individual and institutional health care providers can minimize any problems that do arise. Indeed, any short-term difficulties pale beside the probleuns attendant to the current system of insuring medical malpractice, a system neither the public nor the provider can afford to retain. 
APPENDIX I

ISO POLICY YEAR, CLAIM FREQUENCY PER 100 INSURED PHYSICIANS, 1966-1973

(Developed to 123 months of maturity)

\begin{tabular}{|c|c|c|}
\hline $\begin{array}{c}\text { Policy Year } \\
\text { Ending } \\
\text { December } 31\end{array}$ & Actual & $\begin{array}{c}\text { Exponential } \\
\text { Line of } \\
\text { Best Fit }\end{array}$ \\
\hline 1966 & 1.741 & 1.573 \\
\hline 1967 & 1.925 & 1.763 \\
\hline 1968 & 1.835 & 1.976 \\
\hline 1969 & 2.105 & 2.214 \\
\hline 1970 & 2.125 & 2.481 \\
\hline 1971 & 2.469 & 2.780 \\
\hline 1972 & 3.299 & 3.115 \\
\hline 1973 & 4.149 & 3.491 \\
\hline
\end{tabular}

Source: Questionnaire Re Medical Professional Liability Insurance, Technical Appendix, in Hearings on S.482, S.215, S.188 Before the Subcomm. on Health of the Senate Comm. on Labor and Public Welfare, 94th Cong., 1st Sess. 568 (1975).

\section{APPENDIX II}

ISO POLICY YEAR, CLAIM FREQUENCY PER $\$ 100,000$ OF PREMIUM, FOR HOSPITAL PROFESSIONAL

LIABILITY, 1967-1973

(Developed to 123 months of maturity)

$\begin{array}{ccc}\begin{array}{c}\text { Policy Year } \\ \text { Ending } \\ \text { December } 31\end{array} & \text { Actual } & \begin{array}{c}\text { Exponential } \\ \text { Line of } \\ \text { Best Fit }\end{array} \\ 1967 & 2.613 & 2.363 \\ 1968 & 2.567 & 2.651 \\ 1969 & 2.875 & 2.975 \\ 1970 & 3.139 & 3.337 \\ 1971 & 3.570 & 3.744 \\ 1972 & 4.092 & 4.200 \\ 1973 & 5.211 & 4.712\end{array}$

Source: Insurance Services Office, 1975 Review of Hospital Professional

Liability Insurance, Exhibit 2, Sheet 2 (June 12, 1975). 
